\title{
POTENSI BAHASA SUNDA DALAM MEMPERKAYA BAHASA INDONESIA
}

\author{
Umi Kulsum \\ Balai Bahasa Provinsi Jawa Barat \\ Korespondensi: Jalan Sumbawa Nomor 11, Bandung, Jawa Barat \\ Pos-el: umikulsum_1973@yahoo.co.id
}

\begin{abstract}
Abstrak
Bahasa Indonesia akan senantiasa berkembang sesuai dengan perkembangan penuturnya. Bahasa Indonesia juga banyak menggunakan kosakata dari luar yang dianggap lebih mewakili konsep, gagasan, atau ide tertentu. Bahasa yang menjadi sumber serapan bagi bahasa Indonesia adalah bahasa Melayu, bahasa daerah lain di Indonesia, atau bahasa asing. Sebagai bahasa daerah dengan penutur yang cukup banyak, bahasa Sunda mempunyai kemantapan, baik dalam korpus (tata bahasa, kamus) maupun dalam pemakaiannya. Tulisan ini bertujuan untuk mendeskripsikan (1) kosakata bahasa Sunda yang berpeluang masuk ke dalam bahasa Indonesia, dan (2) karakteristik kosakata tersebut dilihat dari segi makna, kategori, dan bentuk. Metode yang digunakan dalam penelitian ini ialah metode deskriptif. Hasil temuan menunjukkan bahwa kosakata bahasa Sunda banyak yang berpeluang menjadi kosakata bahasa Indonesia, terutama kosakata yang memiliki konsep, gagasan, atau ide yang tidak ada dalam bahasa Indonesia, baik menyangkut istilah kekerabatan, berkaitan dengan fisik manusia, nama tumbuhan dan bagiannya, aktivitas badan dan aktivitas sehari-hari, aktivitas terkait benda, rasa sakit, sifat manusia, alam dan keadaan, nama penyakit maupun konsep lainnya yang tidak ada dalam bahas Indonesia. Hal tersebut dibuktikan dengan banyaknya kosakata Sunda yang masuk ke dalam wacana dan menjadi interferensi leksikal (atau harus dimiringkan) dalam media massa berbahasa Indonesia. Selain itu, kosakata yang berkaitan dengan budaya Sunda, seperti nama kesenian, alat musik, tradisi, dan sastra Sunda berpeluang juga menjadi kosakata bahasa Indonesia atau setidaknya menyumbang Kamus Besar Bahasa Indonesia cetakan selanjutnya.
\end{abstract}

Kata kunci: Bahasa Indonesia, KBBI, kosakata, bahasa Sunda

\begin{abstract}
Indonesian will continue to evolve as its speakers grow. Indonesian uses plenty of vocabulary from the outside which is considered to better represent particular concepts or ideas. The languages that have been the sources for borrowing are Malay, regional languages in Indonesia, or foreign languages. As a local language with a significant number of speakers, Sundanese is established, both in the corpus (grammar, dictionaries) as well as in its use. This paper aims to describe (1) Sundanese vocabulary is likely to enter into Indonesian, and (2) the characteristics of such Sundanese vocabulary is likely to enter into Indonesian in its meaning, category and form. The method used in this research is descriptive. A large number of Sundanese words are likely to
\end{abstract}


be the vocabulary of Indonesian, especially those concerning a concept, or an idea that does not exist in Indonesian, e.g. kin terms, human physical nature, names of plants and parts, the activity of the body and everyday activities, activities related to objects, pain, human nature, the nature and circumstances, and names of diseases. This is evidenced in the number of Sundanese vocabulary in Indonesian passages and lexical interferences in Indonesian mass media. Moreover, the vocabulary related to Sundanese culture, such as names of arts, musical instruments, traditions and literary are likely to also be the Indonesian vocabulary and contribute to the next edition of the Great Dictionary of the Indonesian Language.

Keywords: vocabulary, Sundanese, Indonesian, Indonesian dictionary

\section{PENDAHULUAN}

Setiap masyarakat pemakai suatu bahasa memiliki kesepakatan tentang bahasanya, baik dari segi struktur atau kosakatanya. Kata-kata yang terdapat pada suatu bahasa tentunya merupakan kata yang khas yang menjadi ciri bahasa tersebut. Akan tetapi, tidak menutup kemungkinan akan adanya kesepakatan untuk menggunakan kosakata dari bahasa luar yang dianggap lebih mampu mewadahi konsep, gagasan, atau ide sehingga akan memperkaya bahasa tersebut. Masyarakat bahasa yang bersangkutan melakukan penyerapan (borrowing) unsur bahasa, terutama kosakata, dari bahasa lain. Penyerapan (atau biasa disebut juga dengan peminjaman) menjadi salah satu penyebab perkembangan sebuah bahasa.

Bahasa Indonesia akan senantiasa berkembang sesuai degan perkembangan masyarakat penuturnya. Bahasa Indonesia dalam hal ini juga banyak menggunakan kosakata dari luar yang dianggap lebih mewakili konsep, gagasan, atau ide. Bahasa yang dapat menjadi sumber serapan bagi bahasa Indonesia berasal dari bahasa Melayu (sumber bahasa Indonesia), bahasa daerah lain di Indonesia, atau bahasa asing.

Dalam pembentukan istilah perlu diperhatikan persyaratan di antaranya:
(1) kata atau frasa yang paling tepat untuk mengungkapkan konsep termaksud dan yang tidak menyimpang dari makna itu, (2) paling singkat di antara pilihan yang tersedia yang mempunyai rujukan sama, (3) bernilai rasa (konotasi) baik, (4) sedap didengar (eufonik), dan (5) sesuai kaidah bahasa Indonesia.

Bahasa Inggris, Belanda, Arab, Portugis, dan Sansekerta adalah beberapa bahasa asing yang dijadikan sumber unsur serapan asing dalam berbagai kosakata atau istilah bahasa Indonesia. Bahasa Melayu dan bahasa daerah tetap dijadikan sebagai sumber utama bahasa Indonesia dan bahasa asing dijadikan sebagai sumber tambahan dalam hal pemerkaya bahasa Indonesia (Badan Pengembangan dan Pembinaan Bahasa, 2012:1). Penyerapan istilah untuk menjadi istilah Indonesia dilakukan berdasarkan pada hal-hal berikut.

a. Istilah yang akan diserap meningkatkan ketersalinan bahasa sumber dan bahasa Indonesia secara timbal balik (intertranslatability) mengingat keperluan masa depan.

b. Istilah yang akan diserap mempermudah pemahaman teks oleh pembaca Indonesia karena dikenal lebih dahulu.

c. Istilah yang akan diserap lebih ringkas jika dibandingkan dengan terjemahan Indonesianya.

d. Istilah yang akan diserap mempermudah kesepakatan 
antarpakar jika padanan terjemahannya terlalu banyak sinonimnya.

e. Istilah yang akan diserap lebih cocok dan tepat karena tidak mengandung konotasi buruk.

(Badan Pengembangan dan Pembinaan Bahasa, 2012:6).

Proses penyerapan istilah asing, dengan mengutamakan bentuk visualnya, dilakukan dengan cara yang berikut.

a. Penyerapan dengan penyesuaian ejaan dan lafal, misalnya camera [kæm ra]==kamera [kamera].

b. Penyerapan tanpa penyesuaian ejaan, tetapi dengan penyesuaian lafal, misalnya bias [baī $\mathrm{s}$ ]== bias [bias].

c. Penyerapan tanpa penyesuaian ejaan dan lafal, dilakukan jika istilah itu juga dipakai secara luas dalam kosakata umum, istilah itu tidak ditulis dengan huruf miring (dicetak dengan huruf tegak), misalnya golf= golf.

(Badan Pengembangan dan Pembinaan Bahasa, 2012:6-7).

Dalam kaidah penyerapan dinyatakan bahwa bahasa daerah merupakan perioritas kedua, setelah bahasa Melayu, untuk menjadi bahasa sumber bagi bahasa Indonesia, sementara bahasa asing diposisikan sebagai alternatif terakhir. Jadi, berdasarkan prioritas, jika ada konsep baru yang belum ada kosakatanya dalam bahasa Indonesia, dicari dulu dalam bahasa Melayu (melalui proses penerjemahan), jika tidak ditemukan, dicari dalam bahasa daerah, dan jika tetap tidak ditemukan dalam bahasa daerah, baru diserap dari bahasa asalnya, yaitu bahasa asing.

Alasan prioritas bahasa sumber adalah bahasa Melayu dan bahasa daerah merupakan langkah yang tepat dalam pelestarian bahasa Melayu dan bahasa daerah. Selain itu, hal tersebut bertujuan untuk mempertahankan identitas bahasa Indonesia supaya tidak terlalu banyak kosakata bahasa asing yang diserap ke dalam bahasa Indonesia, sebagaimana pernyataaan Remy Silado yang menjadi judul bukunya, yaitu 9 dari 10 Kata Bahasa Indonesia Adalah Asing. Jadi, masuknya kosakata daerah merupakan jawaban Badan Bahasa atas kritik yang menyebutkan mengapa lema-lema banyak mengadopsi bahasa asing. Oleh karena itu, upaya untuk mencari kosakata yang berpeluang masuk ke dalam bahasa Indonesia, baik dari bahasa Melayu maupun bahasa daerah yang ada di Indonesia, perlu dilakukan dan ditingkatkan.

Bahasa daerah di Indonesia cukup banyak, di antaranya adalah bahasa Sunda. Sebagai bahasa daerah dengan penutur yang cukup banyak, bahasa Sunda mempunyai kemantapan, baik dalam korpus (tata bahasa, kamus) maupun dalam pemakaiannya. Bahasa Sunda sudah mempunyai beberapa kamus, baik dwibahasa maupun kamus umum, mempunyai buku tata bahasa, dan bentuk-bentuk lainnya yang mendukung kaidah-kaidah yang terdokumentasikan dalam bentuk buku. Selain itu, beberapa media massa berbahasa Sunda, baik surat kabar, majalah, maupun tabloid, hidup dan berkembang di wilayah penutur bahasa tersebut (sebagian besar Provinsi Jawa Barat, sebagian besar Provinsi Banten, dan sebagian kecil Provinsi Jawa Tengah).

Kamus Besar Bahasa Indonesia (Sugono,2008) atau KBBI, sebagai salah satu sarana pendokumentasian kosakata bahasa Indonesia sudah sampai edisi ke4. Dinyatakan dalam KBBI Edisi Keempat bahwa KBBI Edisi I terdiri atas 62.000 lema, KBBI Edisi II terdiri atas 72.000, Edisi III terdisi atas 78.000 lema, dan Edisi IV terdiri atas 90.049 lema. Edisi terakhir, yaitu Edisi IV terbit pada tahun 2008. Penambahan dari edisi sebelumnya, yaitu Edisi III, ke Edisi IV cukup signifikan. Hal tersebut disebabkan masuknya kosakata budaya daerah dalam kamus tersebut. Kosakata budaya daerah ditandai dengan label 
tertentu. Untuk kosakata budaya Sunda dilabeli dengan $S d$.

Pendataan kosakata Melayu dan kosakata bahasa daerah, terutama yang berpeluang menjadi kosakata bahasa Indonesia, perlu dilakukan dan ditingkatkan. Tujuan dari penelitian ini adalah untuk mendeskripsikan (1) kosakata dari bahasa Sunda yang berpeluang masuk ke dalam bahasa Indonesia/Kamus Besar Bahasa Indonesia atau memperkaya bahasa Indonesia, dan (2) karakeristik kosakata tersebut dilihat dari segi makna, kategori, dan bentuk.

\section{METODE}

Metode yang digunakan dalam penelitian ini ialah metode deskriptif. Metode deskriptif dalam tulisan ini dipakai untuk mencari dan menganalisis data. Pengambilan data dilakukan dengan studi pustaka, yaitu mengumpulkan kosakata dari beberapa kamus Sunda, buku-buku, dan media massa berbahasa Sunda. Selain itu, data juga diperoleh dari media massa berbahasa Indonesia yang mengandung kosakata Sunda, baik yang terbit wilayah berbahasa Sunda ataupun yang terbit di Jakarta. Kemudian, data tersebut dicatat dan dikartukan. Metode yang digunakan dalam kajian ialan metode padan referensial, yaitu salah satu metode yang mengandalkan unsur-unsur yang berasal dari bahasa itu sendiri, yaitu dilihat dari maknanya. (Sudaryanto, 1993).

\section{HASIL DAN PEMBAHASAN}

1. Kosakata Sunda dalam Kamus Besar Bahasa Indonesia Edisi IV

Dalam KBBI Edisi IV sudah tercantum beberapa kosakata Sunda, di antaranya ialah (1) agan 'juragan' (hlm.15). Kata agan merupakan bentuk pangkas dari juragan. Selain itu, kata (2) ajengan 'orang terkemuka, terutama guru agama Islam, kiai (hlm.23) juga menambah jumlah lema dalam KBBI tersebut. Kata (3) akang 'kakak (lakilaki) abang, aa' (hlm. 23) juga menjadi bagian dari KBBI. Padahal, ketiga kosakata tersebut, yaitu agan, ajengan, dan akang sudah ada padannnya dalam bahasa Indonesia, yaitu juragan, kiai, dan kakak laki-laki/abang. Kata yang berpeluang, yaitu kata yang belum ada dalam bahasa Indonesia mengenai konsep tersebut, khususnya dalam kekerabatan adalah teteh 'kakak perempuan' dan ua 'kakak ibu atau bapak (orang tua). Dalam bahasa Indonesia hanya ada kata kakak (baik laki-laki maupun perempuan) dan paman/bibi (adik ibu atau bapak).

Dalam KBBI Edisi IV ada bentuk tertentu yang belum begitu dikenal di masyarakat umum, yang lebih dikenal adalah bentuk turunannya. Contohnya adalah kata anjang $v$ dengan makna 'mengunjungi'. Istilah yang dikenal pada masyarakat Indonesia secara umum adalah kata anjangsana yang berkategori nomina dengan makna 'kunjungan untuk melepaskan rasa rindu atau kunjungan ke rumah tangga, saudara, kawan lama, atau sahabat'.

Dalam KBBI Edisi IV juga dikenal kosakata dan konsep yang belum ada dalam bahasa Indonesia. Jadi, jika kata bahasa Sunda ini akan diterjemahkan ke dalam bahasa Indonesia dinyatakan dengan beberapa kata. Kata baru dengan konsep baru tersebut, di antaranya adalah angkaribung $v$ dengan makna 'membawa barang yang banyak dan bermacam-macam dengan tangan kanan dan kiri '(hlm.26). Contoh: dia angkaribung dengan oleh-oleh. Kata ini menjadi kosakata baru untuk bahasa Indonesia karena tidak ada kata yang mewakili konsep ini.

Nama tumbuhan bahasa Sunda juga masuk dalam KBBI Edisi IV, di antaranya antanan 'tumbuhan menjalar yang dijadikan lelap atau obat: Hydrocotyle sibthovpioides (hlm.73). 
Begitu juga dengan nama hewan, di antaranya adalah bagong $n$ babi hutang, celeng (hlm.114).

Kosakata yang terkait dengan budaya menjadi klasifikasi yang sangat banyak, di antaranya adalah aom 'gelar untuk bupati zaman dulu' (hlm. 79), beluk $n$ 'kesenian berupa pembacaan cerita dengan ditembangkan secara bergilir' (hlm. 165), candoli $n$ 'perempuan yang bertugas menjaga dan menyediakan makanan dalam pesta, kenduri (hajatan)' (hlm. 241), boboko $n$ 'tempat nasi terbuat dari anyaman bambu atau rotan' (hlm. 202), gacong $v$ menuai padi di sawah orang lain dan mendapat upah sepersepuluh bagi dari tuaiannya (hlm. 402), dan gawul $n$ 'alat untuk menangkap ikan yang terbuat dari kayu pohon aren (kawung)' (hlm. 422).

Contoh ukuran dalam bahasa Sunda juga ada yang masuk dalam KBBI, yaitu saing $n$ 'satuan yang jumlahnya sama dengan 200 ikat (ttg padi)' (hlm. 236). Contoh sifat adalah deleka $a$ 'suka mencelakai atau menyakiti orang lain' (hlm. 308). Contoh yang terkait dengan fisik adalah demplon $a$ 'cantik dan montok' (hlm. 311). Ada juga contoh rasa, yaitu kabita $v$ 'tertarik dan menginginkan sesuatu yang dimiliki atau yang dialami orang; (hlm. 597). Makanan populer dari bahasa Sunda juga mewarnai KBBI, di antaranya adalah masuknya kata cilok 'bakso yang terbuat dari tepung kanji dan dihidangkan dengan ditusuk seperti satai' .

Hal yang menarik lainnya dari masukknya kosaata Sunda ke dalam KBBI Edisi IV adalah kosakata tertentu yang disertai turunannya (kata berimbuhan). Imbuhan yang dilekatkan tentu saja imbuhan bahasa Indonesia. Padahal, imbuhan bahasa Indonesia berbeda dengan imbuhan bahasa Sunda. Contohnya adalah kata bodor $n$ 'lawak; badut', dengan kata turunan membodor $v$ 'berbuat jenaka (lucu); melucu' (hlm. 203). Dalam bahasa Sunda kata turunannya adalah ngabodor. Contoh lainnya adalah kata aben 'membakar mayat di Bali' diturunkan menjadi mengaben, umumnya digunakan ngaben karena afiks bahasa Bali dalam konteks ini sama dengan bahasa Sunda, yaitu nga-

Ada kendala dalam pemerkayaan bahasa Indonesia melalui kosakata bahasa Sunda. Kendala tersebut adalah tidak samanya vokal dalam bahasa Indonesia dan Sunda. Dalam bahas Sunda terdapat vokal /eu/, tetapi vokal ini tidak ditemukan dalam bahasa Indonesia. Dengan demikian, kosakata bahasa Sunda yang mengandung /eu/ mengalami kendala untuk diserap ke dalam bahasa Indonesia. Padahal, banyak sekali kosakata bahasa Sunda yang berpotensi, tetapi mengandung /eu/. Contohnya adalah kata cileuncang 'air tergenang setelah hujan yang cepat surut lagi', kadeudeuh 'yang disayangi' dan keukeuh 'teguh pendirian dalam konteks yang negatif'. Ketiganya belum masuk KBBI sementara pemakaiannya sudah sangat tinggi dalam surat kabar berbahasa Indonesia. Terkait dengan vokal /eu/ ini, ada satu kosakata yang mengandung vokal /eu/ yang masuk dalam KBBI, yaitu geulis yang ditulis dengan gelis 'indah, cantik, elok, bagus' (hlm. 432). Ini berarti bahwa telah terjadi penyesuaian ejaan dalam penyerapan kosakata tersebut.

Dapat dinyatakan bahwa kosakata bahasa daerah (Sunda) dapat masuk ke dalam KBBI dan menjadi bagian dari bahasa Indonesia jika bersifat khas (budaya), mengandung konsep yang tidak ditemukan dalam bahasa Indonesia, dan umumnya terdapat dalam media massa, khususnya media yang berbahasa Indonesia sehingga jelas terlihat bahwa kosakata tersebut diperlukan untuk bahasa Indonesia. 


\section{Kosakata Bahasa Sunda yang Berpeluang Masuk ke dalam Bahasa Indonesia}

\subsection{Verba}

\subsubsection{Posisi Duduk}

Posisi duduk dalam bahasa Sunda banyak macamnya. Hal ini menjadi kekayaan bahasa Sunda yang tidak menutup kemungkinan menjadi kekayaan bahasa Indonesia karena konsep yang dinyatakan dalam kosakata tersebut diperlukan dalam bahasa Indonesia dan/atau memperkaya perbendaharaan kosakata bahasa Indonesia. Posisi duduk dalam bahasa Sunda di antaranya adalah (1) an.ce.mon 'duduk bersimpuh (perempuan)', (2) an.de.kak atau anekak atau jem.prak 'duduk sila dilebarkan', (3) an.dep.rok 'duduk bersimpuh rapat tanpa alas', (4) an.jeucle disebut juga nyengcle 'duduk santai pada tempat yg agak tinggi', (4) ca.me.ot atau caneot 'duduk sendiri sambil diam seribu basa dengan posisi yang tidak berubah', (5) cam.pe.go atau cam.pe.re.go atau ci.ngo.go atau ci.nut.rung atau ca.nu.kul, atau can.de.luk 'duduk atau jongkok seperti ada yang sedang ditunggu-tunggu, (6) ca.mu.nuk 'duduk jongkok di tempat agak gelap dengan berkerudung kain', (7) dang.geuak, dang.heuak, nga.dang.heuak 'duduk sambil melentingkan punggung dicondongkan ke belakang', (8) deng.kak, nga.deng.kak 'duduk dengan kaki sebelah-menyebelah (naik kuda dsb.)', (9) jeng.je.he, nga.jeng.je.he' duduk santai di kursi', (10) sang.heuy, nyang.heuy 'duduk atau telungkup dengan dagu ditopang oleh bantal', dan (11) sang.hun.jar nyang.hun.jar 'duduk sambil menjulurkan kedua belah kaki'.

\subsubsection{Budaya Bertani}

Verba terkait dengan budaya pertanian yang tidak menutup kemungkinan menjadi kekayaan bahasa Indonesia karena konsep yang dinyatakan dalam kosakata tersebut diperlukan dalam bahasa Indonesia dan/atau memperkaya perbendaharaan kosakata bahasa Indonesia adalah (1) gem.pel, nga.gem.pel $v$ 'menuai padi tidak dengan tangkainya', (2) po.po.le, mo.po.le $v$ 'mengulangi panen (ubi, jagung, kacang tanah, dll), kalau-kalau ada yang terlewat atau belum dipetik karena masih muda', (3) mo.po.le $v$ 'memetik penghabisan atau mengambil buah-buahan atau umbi-umbian karena waktu tadi (sebelumnya) belum matang, dan (4) sal.ba, di.sal.ba.keun $v$ 'diizinkan untuk dipetik siapa saja (hasil tanaman)'.

\subsubsection{Aktivitas Badan}

Verba terkait dengan aktivitas badan yang tidak menutup kemungkinan menjadi kekayaan bahasa Indonesia karena konsep yang dinyatakan dalam kosakata tersebut diperlukan dalam bahasa Indonesia dan/atau memperkaya perbendaharaan kosakata bahasa Indonesia adalah reun.deuk $v$ 'menggerakkan bahu dan badan ke atas dan ke bawah', (2) eu.leu.geug, eu.eu.leu.geug.an $\quad v \quad$ 'menggerakgerakkan leher karena ada makanan dsb. yg sukar ditelan di kerongkongan', dan (3) ke.ke.peh.an $v$ 'menggerak-gerakkan tangan tanda menolak pemberian orang'.

\subsubsection{Aktivitas Manusia Sehari-Hari Verba terkait dengan} kegiatan/aktivitas manusia Sunda seharihari yang tidak menutup kemungkinan menjadi kekayaan bahasa Indonesia karena konsep yang dinyatakan dalam kosakata tersebut diperlukan dalam bahasa Indonesia dan/atau memperkaya perbendaharaan kosakata bahasa Indonesia adalah (1) ko.bok, ngo.bok $1 v$ memasukkan tangan ke dalam suatu wadah yang ada airnya; saat ini sudah sering digunakan kata kobokan 'tempat 
mencuci tangan berupa wadah'; (2) ke.le.tik, nge.le.tik $v$ 'membuat minyak goreng dari kelapa parut, kemudian diremas dengan air dan santannya direbus; saat ini sering diungkap minyak keletik atau minyak kelapa murni.

Kosakata berkategori verba yang menyatakan kegiatan sehari-hari lainnya adalah (3) kom.pet, ngom.pet.keun $v$ 'melipatkan daun pisang supaya ringkas', (4) ku.kud $v$ 'menyimpan kembali barang-barang (dagangan) sesudah pasar usai', (5) ku.si.wel $1 v$ 'menunjukkan cara mengambil barang kecil dari saku atau dompet'; $2 v$ 'mengerjakan sesuatu yang mudah dan cepat sekali selesai, mengikatkan tali sepatu', (6) ka.ra.tak $v$ 'mencari-cari sesuatu sambil membuka atau mengakat-akat barang tempat kemungkinan sesuatu itu disimpan', dan (7) en.cod, ngen.cod.keun $v$ 'meminjam uang atau barang terus kabur, menghilang'.

Tak kalah seringnya kata (8) ban.cak.an dan (9) botram muncul mewarnai surat kabar berbahasa Indonesia yang terbit, khususnya, di daerah Sunda. Keduanya terkait dengan kegiatan makan-makan (makan bersama). Selain itu, ada juga kata (10) nye.ker $v$ 'tidak menggunakan alas kaki', (11) pa.hu.gi, ma.hu.gi $v$ 'memberi sesuatu kepada kekasih (laki-laki kepada perempuan)', dan (12) paido, maido $v$ 'menyalahkan pekerjaan orang lain yang telah dikerjakan dengan sungguhsungguh yang sering tercantum dalam surat kabar berbahasa Indonesia'.

\subsubsection{Aktivitas Terkait Benda}

$$
\text { Kata (1) ga.ri.dus, }
$$

di.ga.ri.dus.keun $v$ 'dijual murah karena ingin cepat laku', (2) ko.loh.kor, ngo.loh.kor $v$ lepas, tidak melekat pada bungkusnya atau kulitnya (dodol, wajik, dsb), (3) pe.le.nge $v$ 'terbuka sedikit (pintu, jendela, dsb), (4) mu.lek $v$ tidak keluar (asap dalam ruangan tertutup), dan (5) pe.re.jel, me.re.jel $v$ keluar karena ditekan (pasta gigi, cat minyak, dsb.) kerap diucapkan ketika berbahasa Indonesia sebagai kosakata yang sulit dicarikan padanan yang tepat dalam bahasa Indonesia.

\subsubsection{Rasa Sakit}

Si Kabayan menjadi ikon Sunda.

Kata ini berasal dari (1) ba.bay, ka.ba.bay.an $v$ buang air besar mencretmencret yg tak tertahankan, bukan pada tempatnya dan konsep ini tidak ada padanannya dalam bahasa Indonesia sehingga berpeluang menjadi kosakata bahasa Indonesia. Juga kata (2) re.ro $v$ 'berbicara tak jelas karena lidahnya terasa berat, seperti orang yang akan meninggal' dan (3) eu.reup-eu.reup $v$ 'gangguan dl pernafasan sewaktu tidur, menimbulkan impian yang menakutkan, sedangkan melarikan diri atau berteriak minta tolong juga tidak bisa yang berpotensi menjadi bahasa Indonesia.

\subsubsection{Lain-Lain}

Ada kosakata yang terkait dengan berpakaian dan berdandan yang menarik dalam bahasa Sunda, yaitu kata (1) bu.sil $v$ 'memakai pakaian yg sudah tidak pantas (layak lagi) dipakai oleh orang terhormat' dan (2) reun.ceum $v$ 'memakai perhiasan yang banyak memakai intan atau berlian'. Keduanya sering digunakan dalam media massa berbahasa Indonesia. Kosakata lainya yang dapat memperkaya bahasa Indonesia adalah (3) rong.hok $v$ 'tampak orang banyak yang melihat dari jendela atau dari pintu', (4) reng.kong $v$ 'cara membawa padi dengan tongkat bambu atau pikulan yang menimbulkan bunyibunyian karena ujung bambu tersebut sengaja dilubangi dan diminyaki', (5) so.gek $v$ 'tercukil at tertusuk sedikit', dan (6) ta.ta.le.pa $v$ 'berpindah-pindah dari seorang kepada orang lain'. 


\section{Nomina}

\subsection{Berkaitan dengan Fisik Manusia}

Ada kata (1) lam.pir $n$ 'bibir yang penuh ludah merah ketika makan sirih atau berminyak setelah makan sesuatu yang berlemak dalam bahasa Sunda. Kata Mak lampir dalam ceritacerita kemungkinan besar berasal dari lampir. Hal tersebut dapat dibuktikan dengan ciri bibir Mak Lampir. Contoh lainnya yang berkaitan dengan fisik manusia adalah (2) pe.cong $n$ 'mata yang bertitik putih pada bagian hitamnya'(3) ce.da $1 n$ bekas luka; $2 n$ pernah melakukan kejahatan, dan (3) pa.rin.di.kan $n$ bagian perut dan pinggang sebelah bawah

\subsection{Kesenian}

Sangat banyak kosakata terkait kesenian yang terbagi atas alat dan nama kesenian yang ada dalam data penelitian.

\section{A. Alat}

\section{Ada istilah (1) ang.klung} gub.rag $n$ 'sejenis alat musik angklung yang sering dimainkan dalam pertunjukan atau aktraksi karena sifatnya yang aktraktif, yaitu dengan berjongkok, meloncat bahkan sampai jatuh dan tiduran (gubrag 'jatuh'), (2) dog.dog lo.jor $n$ 'alat musik seperti gendang panjang (lojor 'panjang') yang sisinya tidak ditutup (bolong); diameternya lebih kecil dari yang biasa dan merupakan alat musik khas daerah Banten Kidul (Pakidulan) yang biasa dimainkan bersma dengan angklung, (3) cam.pa.la $n$ 'pemukul dari kayu yang dipergunakan oleh dalang untuk memukul kotak wayang dan kecrek, (4) kem.pul $n$ alat pelengkap gamelan, (5) ta.ra.wang.sa $n$ alat musik gosok dan petik khas Sunda, (6) to.leat $n$ alat musik tiup (sejenis seruling) yang mempunyai 4 lubang dan biasa dimainkan untuk mengiringi pupuh, dan (7) tan.ji $n$ sejenis rebana yang besar.

\section{B. Nama/Jenis Kesenian}

(1) Gon.dong $n$ adalah jenis kesenian muda-mudi pada saat panen, biasanya dimainkan menggunakan alu dan lesut yang mengiringi berbalas pantung dan ketuk tilu, (2) ji.peng $n$ terdiri atas tanji, topeng, dan kendang yang berfungsi sebagai pengiring jalannnya barisan upacara; jipeng ini juga merupakan jenis kesenian khas daerah pakidulan; dahulu biasa dimainkan untuk mengiringi ketuk tilu dan sekarang untuk mengiringi jaipongan, (3) mi.tem.be.yan $n$ upacara adat yang berhubungan dengan pertanian, yaitu upacara menanam atau menuai padi, (4) se.ren ta.un $n$ upacara perwujudan rasa syukur serta penghormatan kepada Dewi Sri, (5) tem.bu.ni $n$ upacara pertama yang dialami oleh seorang bayi yang baru lahir, yaitu menanam ari-ari, (6) to.ke.cang $n$ permainan anak-anak, berpegangan tangan berhadapan, lalu berbalik menjadi berbelakangan

Sebagai tambahan ada istiah yang terkait dengan kesenian, yaitu (7) ta.ta.lu $n$ lagu permulaan dalam permainan gamelan dsb. untuk menarik perhatian penonton, (8) se.se.bred $n$ pantun, talibun, dsb. yang isinya jenaka, dan (3) tan.dak $n$ lagu kawih yang terikat dalam mantera.

\subsection{DuniaTumbuhan}

Daerah Sunda sangat kaya dengan dunia tumbuhan sehingga tidak mengherankan apabila banyak kosakata yang terkait dengan tumbuhan. Dalam hal ini dibagi atas jenis/nama tumbuhan dan nama bagian tumbuhan.

\section{A. Jenis/Nama Tumbuhan}

Dalam bahasa Sunda terdapat nama tumbuhan (1) ba.ba.dot.an n sejenis tumbuhan kecil, bunganya putih, daunnya bau kambing jantan (kambing jantan disebut badot), biasanya dipergunakan sabagai obat luka ringan, 
(2) se.lang $n$ tumbuh-tumbuhan sebangsa palem, (3) si.ngu.gu $n$ tumbuhan yang daunnya biasa dipakai obat encok, (4) tun.dun $n$ rambutan yang bulu-bulunya pendek sekali, (5) te.pus $n$ tumbuhan hutan berumbi batang, (6) bak.rik $n$ bambu yang diambil dengan akarakarnya, bentuk akarnya biasanya melengkung, gunanya untuk mengait dan menolong pada waktu kebakaran; sekarang akar yg melengkung itu diganti dengan besi, (7) seng.gang $n$ tumbuhtumbuhan liar sebangsa bayam, batangnya berduri, biasa disayur, (8) si.uh $n$ tumbuhan merambat, buahnya sebesar pinang, rasanya asam manis, (9) ke.puh $n$ pohon tinggi, bunganya berbau busuk, daunnya biasa dipakai obat; biji buahnya dapat disambal, mengandung minyak, biasa dipakai untuk pelita atau menggoreng, kayunya dipakai membuat peti mati, perahu dsb., dan (10) su.lang.kar $n$ tumbuhan perdu yang biasa dibuat pagar hidup.

\section{B. Bagian dari Tumbunan}

Pohon kelapa mempunyai kosakata yang bervariasi, di antaranya adalah (1) bi.ru.luk $n$ pentil kelapa (buah yang masih kecil), (2) ba.ra.lak $n$ daun kelapa yg sudah kering dan sudah jatuh dari pohonnya, (3) ta.bo $n$ sabut kelapa muda dan lunak, rasanya manis dan sepet, dan (4) seng.se.rang $n$ potongan tangkai bunga enau yang mencuat untuk ditampung air niranya Untuk pohon pisang dikenal (5) ka.ra.ras $n$ daun pisang yang sudah kering dan (6) si.ru, si.si.ru $n$ secabik daun pisang atau daun kelapa dipakai sebagai sendok.

\subsection{Nama Makanan}

Orang Sunda terkenal dengan kekreatifannya dalam hal kuliner (makanan). Nama makanan yang berpeluang masuk dalam KBBI di antaranya adalah (1) bong.ko $n$ sejenis makanan seperti lontong (dibungkus daun pisang kemudian direbus), (2) ku.kum.bu $n$ makanan yang dibuat dari kacang hijau rebus dicampur gula dan kelapa, kemudian ditumbuk, (3) la.la.yak $n$ adonan (tepung) yang memakai kelapa, kemudian digoreng seperti telur dadar, tetapi tanpa minyak (goreng), (4) an.ce.mon $n$ makanan yang terbuat dari parutan ketela pohon yang dikukus serta diberi parutan kelapa, (5) be.ka makanan berupa ikan basah yang telah diberi garam, lalu dicampur dengan nasi kering sedikit, ditutup rapat selama 2--3 hari, kemudian dicuci, lalu dipepes atau digoreng, dan (6) tao.ji $n$ tahu yang diolah seperti tauco.

\subsection{Hewan}

Dunia hewan juga marak dalam masyarakat Sunda, hewan yang dihidup di air (ikan-ikanan) di antaranya adalah (1) ba.ung ikan sejenis lele, (2) be.rod sebangsa ikan belut, (3) geng.ge.hek sejenis ikan tawes, ekornya kuning, baik dimakan oleh ibu yang sedang menyusui, (4) se.re.wet $n$ ikan kecil bulat panjang yang hidup liar di sawah, (5) tam.pe.le ikan kecil sebangsa sepat, tetapi bulat, (6) sa.lu.sur $n$ sabangsa ikan sungai, (7) so.ro $n$ ikan sungai sebangsa tawes, tetapi agak bulat, serta (8) ba.yong anak ikan gabus.

Selain bangsa ikan-ikanan, nama hewan yang berpeluang menjadi kosakata bahasa Indonesia adalah (9) tung.geu sebangsa kumbang yang sering terdapat dalam batang enau yang membusuk, (10) si.reup.eun $n$ lebah jenis kecil, (11) so.song.ket $n$ serangga sejenis kumbang berwarna hijau bercahaya merah ungu mengkilap, lehernya sering berderik-derik bergesekan, (12) si.ta.ta.ru $n$ ulat besar berduri lunak putih seperti berlumur tepung, bakal kupu-kupu sirama-rama (13) tan.do $n$ sejenis musang yang dapat melayang dari dahan ke dahan, ta.ta.man $n$ semut hitam besar gigitannya sangat sakit, (14) su.ru.pa.ri $n$ ular kecil berbisa, yang biasa keluar 
senja, (15) cang.ku.ra.wok burung yang pandai mengoceh seperti cucakrawa.

\subsection{Penyebutan Waktu}

Penyebutan waktu dalam bahasa Sunda lebih variatif, di antaranya adalah (1) ca.rang.cang ti.hang $n$ waktu setelah fajar, (2) ba.le.bat $n$ cahaya kuning agak kemerahan di sebelah timur sebagai tanda matahari akan terbit dan biasa juga disebut (3) haliwawar.

\subsection{Alat}

Cukup variatif penyebutan untuk kategori alat dalam bahasa Sunda. Alat yang berhubungan dengan mencari ikan, di antaranya (1) bu.bu $n$ alat penangkap ikan, (2) jung.ju.nan $n$ bagian jala yang paling atas (yang paling pojok), (3) ko.rang $n$ tempat ikan, (4) ku.kum.bul $n$ barang yang mengambang pada tali kail supaya umpan tidak mencapai dasar air dan supaya kelihatan jika pancingnya dimakan ikan, (5) sa.ir $n$ alat seperti ayakan untuk menangkap ikan, (6) te.ger $n$ pancing yang dipasang ditancapkan di pinggir sungai, (7) ba.rung.bung $n$ gagang joran pancing dari kayu atau tanduk,

Alat-alat lainnya selain alat yang berhubungan dengan mencari ikan, di antaranya adalah (1) ku.jang $n$ senjata orang Sunda zaman dahulu; sekarang dijadikan lambang berbagai organisasi dan instansi (Divisi Siliwangi, Pemerintah daerah Jawa Barat), (2) ka.bu.yut.an $n$ senjata zaman dahulu (seperti keris, pisau), (3) cap.lak $n$ alat utuk membuat garis-garis di sawah yang akan ditanami padi; dicaplak (sawah yang akan ditanduri) digarisi supaya lurus jajarannya, (4) cu.cu.tik $n$ alat untuk mengaduk atau mencolek dodol dsb., (5) an.dir $n$ bumbung kecil penggulung benang tenun (6) pa.hul $1 n$ bagian busur; panah yang dipegang pada saat menarik tali busur, (7) leu.keur $n$ alat tempat dandang (kosong) yang dibuat dari merang dan berbentuk lingkaran, (8) tam.po.long $n$ tempat ludah yang terbuat dari logam at tembikar), dan (9) te.ce, te.te $n$ injakan dengan ujung jari.

\subsection{Alam}

Kosakata dalam bahasa Sunda yang terkait dengan alam adalah (1) ci.nyu.su $n$ air yang bersih dan jernih yang keluar dari mata air yang biasanya ada di kaki guning atau bukit, biasa disebut juga (2) cipeureu, (3) bulak, (4) rahong, atau (5) sumber, (6) ki.ki.sik $n$ tepi laut yang datar dan berpasir, (7) nam.bo $n$ bekas aliran sungai, (8) le.le.wek $n$ daerah atau lingkungan yang kecil ukuran luasnya, (9) ngep.ruy $n$ hujan yang seperti abu halus yang terbawa angin, (10) ko.le.nyay $n$ cahaya yang kelihatan berkali-kali dan hanya sebentar-sebentar, (11) pa.pa.cal $n$ mulai musim buah-buahan atau padi mulai berbuah, (12) tari.kolot $n$ bekas kampung, (13) te.pis wi.ring $n$ kampung yang sangat jauh dari kota; pedalaman, (14) te.te.lar $n$ tempat yang agak tinggi dari keadaan sekitarnya, (15) ta.meuh $n$ ikat pinggang agak lebar terbuat dari kain, (16) tam.ba.lung $n$ tali pengikat penjahat at pencuri yang tertangkap, (17) tam.bir $n$ cita penyambung kain at kayu penambah lebar meja, (18) sum.bi $1 n$ tongkat pemegang kain pada alat tenun; 2 sejenis paku pada kepala ikat pinggang.

\subsection{Pertanian}

Istilah-istiah yang erat kaitannya dengan bidang pertanian yang berupa nomina di antaranya adalah (1) a.ray $n$ ikatan padi yang kecil sebelum diberkas menjadi satu; ngaray adalah menjemur padi dengan membuka talinya terus dihamparkan, (2) heu.cak $n$ padi tanpa tangkai utama sehingga tidak dapat diikat, (3) ta.jur $n$ kebun buah-buahan, (4) ta.lun $n$ kebun bermacam-macam pohon buah-buahan yang berumur panjang, (5) se.rah $n$ gabah satu dua biji yang terdapat di antara beras, (6) 
po.cong dan (7) ge.deng $n$ sejenis ikatan padi, (8) sa.lay $n$ galah bambu gelondongan untuk menyimpan ikatan padi, (9) so.soh $n$ kulit ari beras, dan (10) seu.hang $n$ sisiran pisang yang paling besar.

\subsection{Bagian dan Alat Rumah Tangga}

Alat-alat rumah tangga di antaranya adalah (1) pa.ri.si.kan $n$ tempat menyimpan rempah-rempah, (2) sa.id $n$ bakul besar, (3) se.rok, se.se.rok $n$ alat ciduk untuk mengangkat makanan dari penggorengan, (4) so.sok $n$ pencedok dari bambu dianyam, (5) su.su.di $n$ tempat nasi dan lauk pauknya dalam hidangan kenduri, (7) tam.pir $n$ nyiru besar (untuk menjemur padi dsb.), dan (8) cang.ko.rang-bong.kang $n$ barang-barang, perabot rumah tangga dsb. yang tidak berharga.

Sementara bagian dari rumah di antaranya adalah (9) ko.bong $n$ kamar tidur kecil, (10) se.gog $n$ bagian rumah atau tanah yang menjorok, (12) se.pen $n$ ruangan kecil tempat menyimpan bahan makanan, dan (13) so.ron.doy, so.som.pang $n$ bangunan tambahan pada rumah atau bangunan induknya.

\subsection{Lain-Lain}

Karena contoh setiap bagian tidak banyak, klasifikasi ini disebut lain-lain. Klasifikasi ini terdiri atas nama penyakit di antaranya adalah (1) tung.gu.ru.wi.sen at turuwisen $n$ bisul kecil pada bibir mata, (2) bong.bot $n$ penyakit anak-anak sejenis cacar, tetapi tidak begitu berbahaya, (3) ti.bar, ti.par $n$ bisul besar bermata banyak. Klasifikasi bunyi-bunyian di antaranya adalah (1) ko.ro.sok $1 n$ bunyi yang lebih keras (nyaring), contohnya buny daun-daun kering yang lebar dan terinjak; $2 n$ daun tembakau kering tidak diracik, (2) ku.cup.rak $n$ bunyi air yang dangkal terinjak atau tertimpa oleh suatu benda; (3) si.lan.tang $n$ gemuruh di udara; hujan silantang - hujan yang bergemuruh di udara, tetapi tidak jatuh ke bumi, (4) se.or $n$ bunyi hujan lebat atau pasir pada atap genting atau pada atap seng, dan (5) seu.hah bunyi mendesis-desis karena kepedasan. Untuk warna dalam bahasa Sunda dikenal (1) so.pal adj warna bulu bagian bawah kaki kuda yang putih keempat-empatnya dan hi.nyay $n$ warna air yang bercampur minyak. Kosakata lainnya adalah (1) pa.wis.tren $n$ urusan wanita, mis mengurus rumah tangga, menjahit, memasak, dsb., (2) pa.ta.ka $n$ penghias di puncak masjid, (3) pa.ta.ngan $n$ perhitungan menurut kartu Cina; perhitungan menurut suatu pengetahuan untuk mengetahui barang yang hilang, (4) me.hong $n$ kotoran berwarna hitam pada dinding, (5) pan.car $n$ kayu bakar yang kering dan cepat menyala (biasanya bambu kering), (6) si.pat $n$ alat rias untuk menghitamkan bibir mata, (7) nad.ran $n$ ziarah ke kuburan (biasanya sambil menebarkan bunga-bungaan), dan (8) munggahan tradisi menyambut bulan Ramadan, dilakukan dengan makan bersama dan berdoa. Nadran dan munggahan sangat berpeluang menjadi bahasa Indonesia karena kedua kata ini sudah sangat umum digunakan dalam berbahasa Indonesia.

\section{Adjektiva}

\subsection{Berhubungan dengan Fisik Manusia}

Keadaan fisik manusia di antaranya adalah (1) ba.yuh.yuh adj gemuk tetapi pantas, dipergunakan untuk orang yang sudah tua, (2) cam.pe.re.nik adj kecil, tetapi menarik atau cantik, dan man.crit adj kecil, tetapi molek.

\subsection{Sifat Manusia}

Sifat manusia dalam bahasa Sunda yang berpeluang masuk ke dalam KBBI adalah (1) berca.li.weu.ra adj banyak bercanda dan terkesan tidak serius dalam belajar dan merupakan kebalikan dari (2) suhud, (3) ga.re.wol 
adj asal jadi; kurang hati-hati dalam melaksanakan pekerjaan, (4) ko.ko.lot be.gog adj dikatakan kepada orang yang masih muda tetapi berlagak seperti orang sudah tua; (5) pun.dung adj tidak mau lagi melaksanakan sesuatu karena kecewa, (6) pe.nal adj hilang harga diri, (7) som.pral adj berani mengeluarkan kata-kata yang jelek atau kasar, dan (8) sing.kil adj menyiapkan diri untuk bekerja kasar.

\subsection{Benda}

Beberapa kosakata bahasa Sunda menyatakan keadaan benda yang kotor dengan (1) be.le.wuk adj kotor oleh debu atau karena jarang mandi, (2) dag.leg adj menempel agak tebal (lemak, daki, dsb), dan (3) nge.res adj terasa kasar (spt ada pasir, mis di atas tikar) Sifat atau keadaan yang mengandung air diungkapkan dengan (3) be.sem adj agak basah; mengandung air, (4) cik.ruh adj banyak airnya dan tampaknya enak (jeruk garut, gulai, dsb.), dan (5) a.duy adj hampir hancur; sangat lembek. Untuk benda pecah digunakan (6) sem.plek adj pecah sedikit sisinya (cangkir, periuk, genting, dsb), (7) lim.bung adj ukuran tinggi (terlalu tinggi) dan yang tidak seimbang dengan besarnya (rumah dan bangunan lainnya). Kata yang berpotensi masuk dalam KBBI untuk buah di antaranya adalah ka.la.me.ro adj (tt buahan) yang keluar kemudian sehingga matangnya pun paling akhir, biasanya buahnya tidak baik (busuk, kecil dsb); kalemorana - ki orang yang kurang maju dalam penghidupannya dibandingkandengan saudarasaudaranya.

\subsection{Nama Penyakit}

Kata (1) ce.le.kit atau ce.le.tit $a d j$ rasa sakit karena dicubit dan turunannya nyelekit atau nyeletit dengan makna merasa sakit mendadak di dalam tubuh, seperti ada yang menusuk-nusuk atau mencubit, merasa sakit oleh perkataan orang lain yang terasa menusuk hati sering digunakan dalam surat kabar yang berbahasa Indonesia. Selain itu, (2) jeung.jeu.rih.eun adj kencing kurang lancar, keluar sedikit-sedikit dan terasa agak sakit dan (3) be.ser adj sebentarsebentar kencing sering menandai surat kabar berbahasa Indonesia. Untuk konsep tidak ada isinya terdapat kata (4) ga.bug adj 1. biji padi yang hampa, biasa disebut juga (5) hapa; (6) gambrang sebutan yang diberikan pada seorang istri yang tidak punya anak, kebalikan dari (7) reundeuy atau (8) bajir.

\subsection{Lain-lain}

Kosakata untuk menyatakan rasa makanan atau minuman dalam bahasa Sunda adalah (1) ga.har adj rasa makanan atau minuman yg menyegarkan karena ada rasa asam, manis, dan enak. Sebaliknya dikenal kata (2) keu.tar adj dengan makna rasa tidak enak dan agak gatal pada lidah diakibatkan oleh kulit jeruk, kulit mangga, dsb; getir. Kata (3) le.ke.tey, nga.le.ke.tey adj dengan makna perlahan-lahan meluncur ke bawah (tanah yang gugur longsor), (4) min.del $a d j$ bertutup mulut karena ada hal-hal yang tidak cocok dengan isi hati, (5) se.rit adj seret dan rapat; yang terkenal adalah sisir serit, yaitu sisir yang sangat rapat dan halus untuk mencari kutu. Kata yang akhir-akhir ini sering tampil dalam media massa adalah (6) sa.la.kat-se.le.ket $v$ berjalan menyelusup melalui rintangan-rintangan, contoh para pengemudi bermotor roda dua. Makan atau minum terlalu banyak biasanya akan menimbulkan (7) olab keluarnya lagi makanan atau minuman. Kata (8) bu.bu.yut.an dapat berpeluang menjadi kata bahasa Indonesia karena sudah sangat banyak yang mengatakan atau menuliskan musuh bubuyutan. Untuk kondisi jalan dikenal kata (9) ta.ra.hal adj sukar ditempuh karena banyak penghalang dan (10) ta.ring.gul 
adj berbatu-batu besar sehingga sukar dilalui.

\section{SIMPULAN}

Berdasarkan data yang telah diperoleh, dapat dinyatakan bahwa kosakata bahasa Sunda banyak yang berpeluang menjadi kosakata bahasa Indonesia, terutama kosakata yang memiliki konsep, gagasan, atau ide yang tidak ada dalam bahasa Indonesia, baik menyangkut istilah kekerabatan, berkaitan dengan fisik manusia, nama tumbuhan dan bagiannya, aktivitas badan dan aktivitas sehari-hari, aktivitas terkait benda, rasa sakit, sifat manusia, alam dan keadaan, nama penyakit maupun konsep lainnya yang tidak ada dalama bahas Indonesia. Hal tersebut dibuktikan dengan banyaknya kosakata Sunda yang masuk ke dalam wacana dan menjadi interferensi leksikal (atau harus dimiringkan) dalam media massa berbahasa Indonesia. Selain itu, kosakata yang berkaitan dengan budaya Sunda, seperti nama kesenian, alat musik, tradisi, dan sastra Sunda berpeluang juga menjadi kosakata bahasa Indonesia atau setidaknya menyumbang Kamus Besar Bahasa Indonesia edisi/cetakan selanjutnya supaya lebih lengkap dan kaya lagi. Penelitian kosakata bahasa daerah yang berpeluang masuk ke dalam bahasa Indonesia perlu terus digalakkan karena bahasa-bahasa daerah banyak yang menyimpan kekayaan berupa kosakata yang menggambarkan lingkungan dan kehidupan penutunya. Selain itu, bahasa daerah, seperti bahasa Sunda, juga akan senantiasa berkembang sesuai dengan perkembangan penuturnya. Data-data penelitian seperti ini perlu ditindaklanjuti agar dapat memperkaya kosakata bahasa Indonesia atau setidaknya menambah kosakata dalam kamus besar bahasa Indonesia edisi/cetakan selanjutnya.

\section{UCAPAN TERIMA KASIH}

Peneliti mengucapkan terima kasih kepada redaksi jurnal Bahasa \& Sastra atas pemuatan artikel hasil penelitian ini.

\section{PUSTAKA RUJUKAN}

Badan Pengembangan dan Pembinaan Bahasa.(2012). Pedoman Umum Pembentukan Istilah. (Cetakan Ketujuh). Jakarta: KDT.

Kata dan r Ungkapan
Asing.(Cetakan Kelima). Jakarta:
KDT.

Sudaryanto.(1993). Metode dan Aneka Teknik Analisis Bahasa. Yogyakarta: Duta Wacana University Press.

Sugono, D.(2008). Kamus Besar Bahasa Indonesia. Edisi IV. Jakarta: PT Gramedia. 